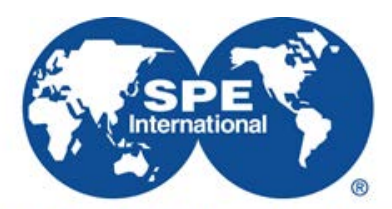

Society of Petroleum Engineers

\title{
SPE-200611-MS
}

\section{Polymer Injection for EOR: Influence of Mobility Ratio and Slug Size on Final Oil Recovery}

José Luis Juárez, CEPSA; Henri Bertin, Université de Bordeaux; Abdelaziz Omari, INP; Carolina Romero, Gilles

Bourdarot, Stephane Jouenne, Danielle Morel, and Valerie Neillo, TOTAL

Copyright 2020, Society of Petroleum Engineers

This paper was prepared for presentation at the SPE Europec featured at 82nd EAGE Conference and Exhibition originally scheduled to be held in Amsterdam, The Netherlands, 8 - 11 June 2020. Due to COVID-19 the physical event was postponed until 8 - 11 December 2020. The official proceedings were published online on 8 June 2020 .

This paper was selected for presentation by an SPE program committee following review of information contained in an abstract submitted by the author(s). Contents of the paper have not been reviewed by the Society of Petroleum Engineers and are subject to correction by the author(s). The material does not necessarily reflect any position of the Society of Petroleum Engineers, its officers, or members. Electronic reproduction, distribution, or storage of any part of this paper without the written consent of the Society of Petroleum Engineers is prohibited. Permission to reproduce in print is restricted to an abstract of not more than 300 words; illustrations may not be copied. The abstract must contain conspicuous acknowledgment of SPE copyright.

\section{Abstract}

Among the many parameters needed to optimize a polymer flood is the choice of polymer viscosity, mobility ratio and polymer slug size that should be injected to maximize oil recovery. In this paper, a new polymer flooding experimental study is addressed to answer two questions. Firstly, considering a given crude oil, what optimal polymer solution viscosity should be injected? And secondly how much polymer solution should be injected during the polymer flood to maximise recovery?

Experiments were carried out using 1D homogeneous Bentheimer cores of similar properties. The cores were oil flooded using crude oil $\left(\mu \mathrm{o}=120 \mathrm{cP}\right.$ at $\left.\mathrm{T}=60^{\circ} \mathrm{C}\right)$ and aged to obtain intermediate wet conditions. The polymer was a partially hydrolysed polyacrylamide (HPAM) dissolved in a moderate salinity brine. The polymer solutions were prepared at different concentrations (from $1500 \mathrm{ppm}$ to $3000 \mathrm{ppm}$ ) to cover a large range of viscosity ratio $\left(R \mu=\mu_{o} / \mu_{p}\right.$ from 2 to 18$)$ which correspond to end-point mobility ratios of 0.5 and 5.4, respectively.

Corefloods results show as expected, that the polymer is more efficient in terms of oil recovery when viscosity ratio is low. In line with polymer flooding theory, we observed at intermediate wettability conditions, that a maximum oil recovery is reached at $M=1(R \mu=5)$ and that oil recovery did not increase when reducing the ratio to $\mathrm{M}=0.5(\mathrm{R} \mu=2)$. However, when considering aspects such as polymer mass required, injectivity concerns and flow stability, we observe two favorable conditions, corresponding $\mathrm{R} \mu=$ 5 and $R \mu=10$, for a mobility ratios of 1 and 7, respectively.

Different polymer slug sizes were injected in the cores at the above conditions $(\mathrm{R} \mu=5$ and $\mathrm{R} \mu=10)$ followed by water flooding (chase water). Both injections (polymer and water injection) were carried out at same flow rate to minimize miscible viscous fingering at the rear of the polymer slug. Results show that an optimal polymer slug size exists for which one can obtain the same microscopic oil recovery than that of continuous polymer injections at $\mathrm{R} \mu=5$ and $\mathrm{R} \mu=10$, an important finding that can impact the economic viability of the process. 
In conclusion, our experimental study shows that at $1 \mathrm{D}$ scale, optimal values of viscosity ratio, polymer slug size and polymer mass injected lead to the same maximum oil recovery obtained by continuous polymer injection. A necessary starting point before upscaling a polymer flood and studying the impact of heterogeneities.

\section{Introduction}

At a macroscopic level wateflooding sweep efficiency is impaired by flow instabilities, especially so called Saffman-Taylor fingering which is due to viscosity contrast between the injected and displaced fluids. Polymer has been used since decades to increase water viscosity and reduce viscous fingering for a better oil recovery. The effect of polymer addition to water is not only to increase the water viscosity but also to reduce the water relative permeability leading to more favorable mobility contrast.

Skauge et al., (2014), show the development of viscous fingering in a bentherimer sandstone and highlighted the effects of an unfavorable mobility ratio, on the final oil recovery. Doorwar and Mohanty; (2015) reported data on the effect of viscosity ratio and capillary number on sweep efficiency, and showed that viscous effects are more determining than the capillary effects.

Viscous instabilities have been studied extensively both in miscible and immiscible conditions showing the importance of viscosity ratio but also of flow conditions and core geometry (Rappoport, 1953, Haagort, 1974; Peters and Flock 1981), The injection of polymer more than 2PV in field applications does not make much sense because in pilots and full-fields the sizes of polymer slugs injected are often between 0.5 and PV. A possibility to optimize the polymer injection by reducing the quantity of polymer injected (with the same recovery rate), is the injection of several polymer slugs (Uzoigwe et al. (1974)) at different viscosities followed by a water injection (chase water). Multi-stage injection with different viscosity ratios (oil / polymer) reduces the formation of viscous immiscible instabilities. However, a new miscible instability may appear if there is no control of the mobility between the aqueous phases.

Vishundas and Chaudhuri, (2017) showed the impact of miscible fingering when the polymer slug is followed by chase water without mobility control. The authors observed that a very low viscosity ratio between the polymer injection and the water (chase water) can dilute the polymer and reduce the effect of the polymer flow. On the other hand, a very high viscosity ratio between the polymer and the water can break the slug of polymer during the flow due to miscible digitations.

To improve the scanning efficiency and to avoid the possible instabilities (fingering) caused by an unfavorable viscosity ratio (oil / aqueous solution), and to optimize the polymer injection, the viscosity ratio (the mobility ratio) and the size of the polymer slug (the mass of injected polymer) represent main research to maximize the oil recovery by polymer flooding. Following a previous study of Juarez Morejon et al. (2018) the objective of our experimental study is to perform corefloods to optimize the viscosity ratio between a crude oil and a polymer solution to determine how much polymer should be injected to maximize oi recovery.

\section{Experiments}

\section{Materials and fluids}

Porous media. Cores were extracted from a Bentheimer outcrop sandstone. Its composition is reported in Table 1 (Peksa et al., 2015). Bentheimer sandstone is known to be homogeneous and initially water wet. 
Table 1-Bentheimer's chemical composition

\begin{tabular}{|l|c|c|c|c|c|c|c|c|}
\hline $\begin{array}{l}\text { Chemical } \\
\text { Composition }\end{array}$ & $\mathrm{SiO}_{2}$ & $\mathrm{Al}_{2} \mathrm{O}_{3}$ & $\mathrm{FeO} / \mathrm{Fe}_{2} \mathrm{O}_{3}$ & $\mathrm{TiO}_{2}$ & $\mathrm{CaO}$ & $\mathrm{MgO}$ & $\mathrm{H}_{2} \mathrm{O}$ & Und. \\
\hline Weight (\%) & 86.47 & 7.31 & 1.14 & 0.7 & 1.21 & 1.76 & 1.2 & 0.21 \\
\hline
\end{tabular}

\section{Experimental procedures}

The cores are $200 \mathrm{~mm}$ long and have a square cross section of $40 \mathrm{x} 40 \mathrm{~mm} 2$. They are prepared between two inlet and outlet plates and wrapped by non-wetting epoxy resin reinforced by glass fiber in order to ensure a unidirectional flow while allowing a good transparency to gamma ray.

\section{Fluids}

\section{Crude oil}

The crude oil used is composed mostly of aliphatic, aromatic and acyclic hydrocarbons, its viscosity is $\mu \mathrm{o}$ $=128 \mathrm{cP}$ at $\mathrm{T}=60^{\circ} \mathrm{C}$.

\section{Brine}

Synthetic brines are prepared from deionized and degassed water $\left(<1 \mathrm{ppm}\right.$ of $\left.\mathrm{O}_{2}\right)$ by addition of $\mathrm{KI}(53 \mathrm{~g} /$ $\mathrm{L})$ and $\mathrm{MgCl} 26 \mathrm{H} 2 \mathrm{O}(7 \mathrm{~g} / \mathrm{L})$ leading to a TDS of $28,288 \mathrm{ppm}, \mathrm{pH}=6.0$. Its viscosity $\mu \mathrm{w}=0.47 \mathrm{cP}$ at $\mathrm{T}=60^{\circ} \mathrm{C}$ and $\mu \mathrm{w}=1 \mathrm{cP}$ at $\mathrm{T}=25^{\circ} \mathrm{C}$. Brine composition was chosen in order to allow wettability change by ageing process. Considering the work of Buckley et al., (1998), wettability depends on many parameters (crude oil composition, brine salinity and $\mathrm{pH}$, solid composition...).Considering our crude oil and the porous medium (mostly $\mathrm{SiO}_{2}$ ). The brine composition (TDS, $\mathrm{pH}$, presence of monovalent $\mathrm{K}+$ and divalent $\mathrm{Mg}^{2+}$ ) was designed to modify initial core wettability from water wet to intermediate wet. This change of wettability was controlled by Amott test (Juarez et al., 2016)

\section{Polymer solution:}

The polymer is a HPAM (Flopaam ${ }^{\circledR}$ 3630S) supplied by SNF Floerger. The following procedural steps were followed to prepare the polymer solution:

1. Preparation of a mother solution $(\mathrm{C}=5000 \mathrm{ppm})$.

2. Dilution of the mother solution to the required concentration.

3. Pre-degradation of the polymer solution. This degradation is achieved mechanically by flowing the polymer solution several times through a capillary tube connected to a valve at high shear rate. This pre-degradation is then quantified in term of viscosity loss

$$
\operatorname{DR}(\%)=\frac{\left(\mu_{0}-\mu_{1}\right)}{\left(\mu_{0}-\mu_{\mathrm{w}}\right)} \times 100
$$

Where $\mu_{\mathrm{w}}$ is the viscosity of brine, $\mu 0$ initial polymer viscosity and $\mu 1$ viscosity of polymer solution after mechanical degradation

4. The last step is filtration of the polymer solution at very low flowrate (without supplementary mechanical degradation) to remove impurities or microgels. The polymer solution is filtrated through a sequence of $8 \mu \mathrm{m}, 5 \mu \mathrm{m}$ and $1.2 \mu \mathrm{m}$ filters.

\section{Experimental setup}

The experimental setup is represented in Figure 1. All corefloods are performed in horizontal position. Each core has three intermediate pressure taps installed at $5.8 \mathrm{~cm}$ of distance between them, and pressure taps are 
also installed to measure the total pressure drop between inlet and outlet. Brine and polymer solution are injected using a volumetric pump (GE healthcare) while oil is stored in a vertical cell and displaced from bottom by a piston pump (Isco). Oil is filtered $(0.45 \mu \mathrm{m})$ before injected in the core to avoid any plugging. Effluents are collected with a fraction collector or a graduated burette. An online densimeter (DP 2510, Anton Paar) can be used for miscible displacement (dispersion experiments). Experiments are performed at $\mathrm{T}=60^{\circ} \mathrm{C}$.

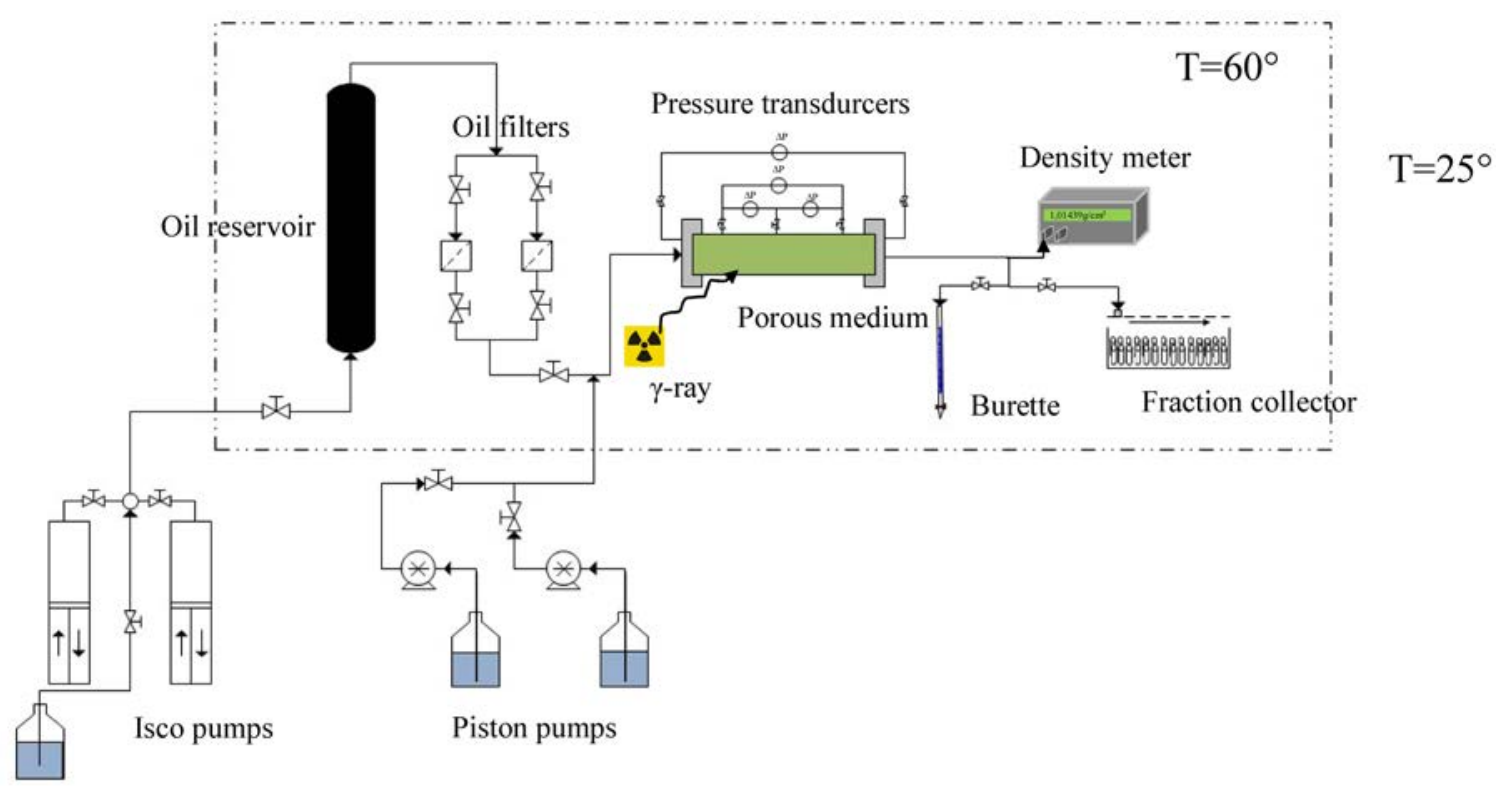

Figure 1-Experimental setup.

\section{Experimental procedure}

The experimental procedure used for water-wet and intermediate-wet cores is similar in all points; except an ageing period, that is set at the end of the initial drainage with crude oil.

1) After core preparation and saturation, porosity is measured by weighting and by $\gamma$ ray attenuation while permeability is determined from Darcy's law by applying different flow rates and measuring the corresponding pressure drop.

2) A dispersion test is performed at $\mathrm{T}=25^{\circ} \mathrm{C}$ and $\mathrm{Q}=0.45 \mathrm{ml} / \mathrm{min}$ by injection of a reduced salinity brine while density variation is measured continuously. Initial brine is then injected.

3) Water is drained out by oil injection at constant flow rate of $15 \mathrm{~mL} / \mathrm{h}$ until reaching the irreducible water saturation (Swi). The oil permeability (Ko@ Swi)1 is then measured by increasing the flow rate and measuring the pressure drop.

4) When using the crude oil, the core is aged during a period varying from 14 to 70 days or more at $\mathrm{T}=$ $60^{\circ} \mathrm{C}$ to modify the initial wettability of the porous medium. Relative permeability to oil at Swi (Ko (a) Swi)2 is measured at the end of ageing.

5) This step corresponds to oil displacement by the aqueous phase in two manners:

a) The polymer solution is injected at fixed capillary number $\left(\mathrm{Ca}=2 \times 10^{-6}\right)$ at different viscosity ratio (mobility ratio) between oil viscosity and polymer solution viscosity $\left(R \mu=\mu_{o} / \mu_{p}\right.$ from 2 to 18$)$.

b) A polymer slug size (from 0.5 to $1 \mathrm{PV}$ ) is injected for viscosity ratio $\mathrm{R} \mu=2, \mathrm{R} \mu=5$ and $\mathrm{R} \mu=$ 10 capillary number $\left(\mathrm{Ca}=2 \times 10^{-6}\right)$ followed by water flooding (chase water) at same flow rate. 
6) When oil production is over and pressure drop is constant, aqueous phase flow rate is increased to minimize the impact of capillary end effects. Sor is measured at this stage by volume balance and by \#-ray attenuation. It is noted that when water injection does not reach Sor, the term Remaining Oil Saturation (ROS) will be used.

7) The brine is injected during $3 \mathrm{PV}$ at very low flowrate $(0.25 \mathrm{ml} / \mathrm{min})$ to remove non adsorbed polymer. Then applying different flow rates and measuring the corresponding pressure drop, we determine the water permeability (Kw@Sor) at Sor in presence of an adsorbed polymer layer.

8) A dispersion test is then performed by injection of a reduced salinity brine while measuring continuously the effluent density to determine the Sor or ROS and its corresponding dispersion coefficient (Juarez-Morejon et al., 2018).

\section{Experimental Results and Discussion}

\section{Polymer solution}

Firstly, a rheological study (Figure 2) was carried out to find the necessary polymer solutions (30\% predegradation) which allow working with the viscosity ratios of $2(\mu \mathrm{p} \approx 58 \mathrm{cP}), 5(\mu \mathrm{p} \approx 23 \mathrm{cP}), 10(\mu \mathrm{p}(11 \mathrm{cP})$ and 20 ( $\mu \mathrm{p} \approx 6 \mathrm{cP})$.
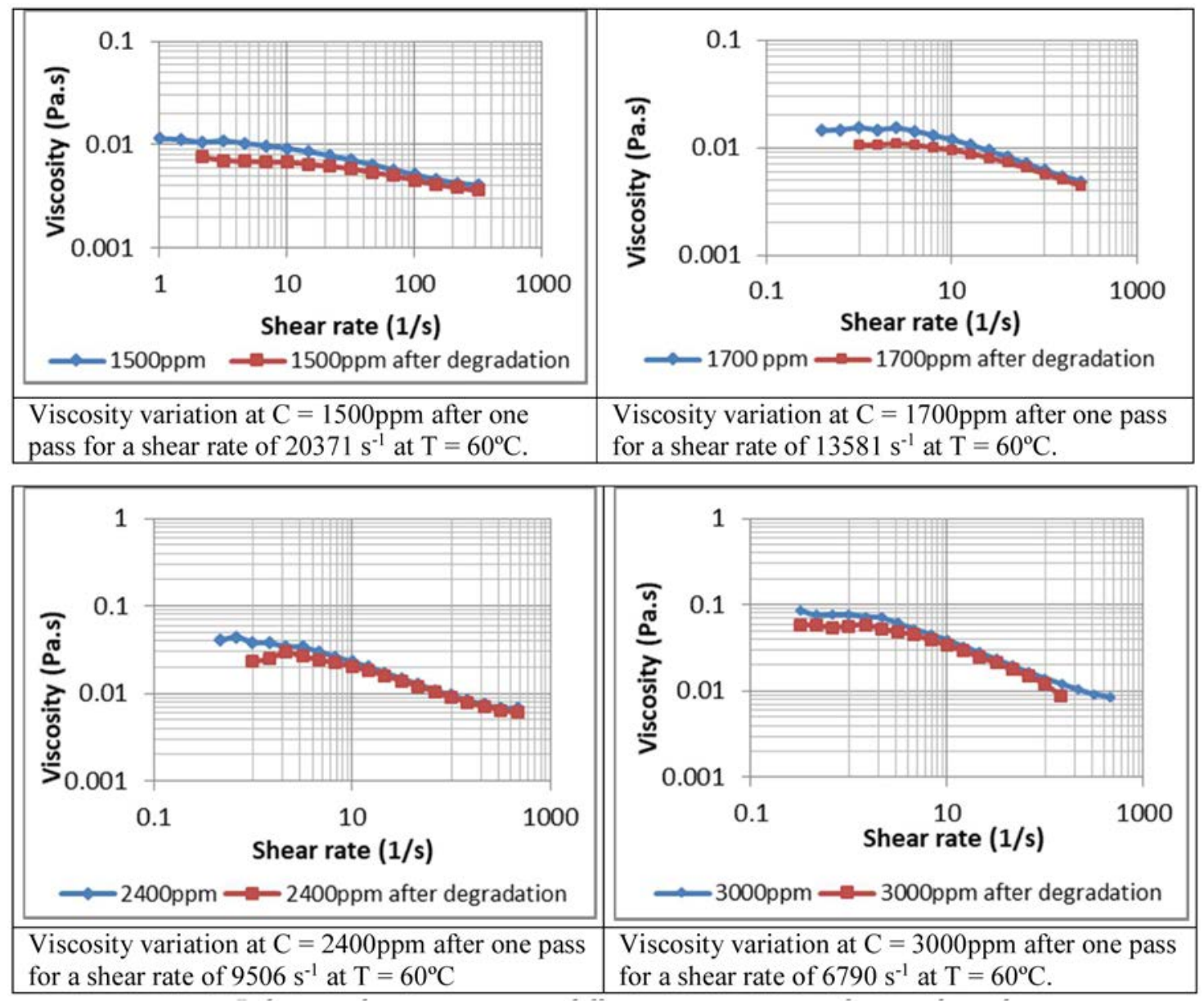

Figure 2-Polymer solution viscosity at different concentration after pre degradation.

From the rheological study of the polymer solutions, the concentrations chosen for the secondary diphasic experiments are $\mathrm{C}=3000 \mathrm{ppm}(\mu \mathrm{p} \approx 54.4 \mathrm{cP}), \mathrm{C}=2400 \mathrm{ppm}(\mu \mathrm{p} \approx 25 \mathrm{cP}), \mathrm{C}=1700 \mathrm{ppm}(\mu \mathrm{p} \approx 10.9 \mathrm{cP})$ and $\mathrm{C}$ $=1500 \mathrm{ppm}(\mu \mathrm{p} \approx 6.7 \mathrm{cP})$ 
Wettability measurement. Cylindrical cores (diameter $=38 \mathrm{~mm}$, length $=60 \mathrm{~mm}$ ) of Bentheimer sandstone were considered to evaluate the change of wettability after ageing considering the Amott test. Experimental procedure to saturate and age the core is similar to the one presented here above. The measured wettability index was Iw=0.075 (Juarez Morejón et al., 2017), showing a change of wettability from water wet to intermediate wet after the ageing process.

\section{Corefloods}

Viscosity ratio. All of the sixteen corefloods presented in this paper (including the influence of viscosity ratio and slug size $)$ were performed at the same at the same value of capillary number $\left(\mathrm{Ca}=2 \times 10^{-6}\right)$.

$$
\mathrm{Ca}=\mu \mathrm{v} / \sigma
$$

Where $\mu$ is the viscosity of the displacing fluid (water or polymer solution), $\mathrm{v}$ is the interstitial velocity and $\sigma$ the interfacial tension. Flow rates were increased at the end of the polymer injection to check possible oil accumulation due to capillary end effect. Experimental results are reported in Table 2 where each experiment is described by a code labelling where PF means (Polymer Flood) and WF means waterflooding, followed by the ratio viscosity (R10 for example, the viscosity ratio is equal to 10), IW means Intermediate Wet, the use of minor letters is to mention duplicate experiments.

Table 2-Experimental data

\begin{tabular}{|c|c|c|c|c|c|c|c|c|c|c|c|}
\hline Experiment & Kw $\left(\mathrm{m}^{2}\right)$ & $\phi$ & Swi & $\begin{array}{c}\text { OOIP } \\
(\mathrm{ml})\end{array}$ & $\begin{array}{c}(\text { Ko@ } @ \text { Swi })_{1} \\
\text { before } \\
\text { ageing }\left(\mathrm{m}^{2}\right)\end{array}$ & $\begin{array}{c}\text { Ageing } \\
(\text { days })\end{array}$ & $\begin{array}{c}(\text { Ko@ @wi })_{2} \\
\text { after ageing } \\
\left(\mathrm{m}^{2}\right)\end{array}$ & $\begin{array}{c}\text { Sor } \\
\text { gamma } \\
\text { ray }\end{array}$ & $\begin{array}{c}\text { Sor } \\
\text { Dispersion } \\
\text { test }\end{array}$ & $\begin{array}{c}\text { Sor } \\
\text { mass } \\
\text { balance }\end{array}$ & $\begin{array}{c}(\mathrm{Kw} @ \text { Sor })_{2} \\
(\mathrm{~m} 2)\end{array}$ \\
\hline PF-R20IW & $2.64 \mathrm{E}-12$ & 0.255 & 0.128 & 70.38 & $3.70 \mathrm{E}-12$ & 71 & $3.49 \mathrm{E}-12$ & 0.353 & 0.381 & 0.363 & $1.88 \mathrm{E}-13$ \\
\hline PF-R10IW & $2.61 \mathrm{E}-12$ & 0.241 & 0.168 & 70.310 & $3.70 \mathrm{E}-12$ & 246 & $3.20 \mathrm{E}-12$ & 0.259 & 0.338 & 0.288 & $5.52 \mathrm{E}-14$ \\
\hline PF-R5IWa & $2.99 \mathrm{E}-12$ & 0.264 & 0.128 & 73.45 & $3.82 \mathrm{E}-12$ & 40 & $3.79 \mathrm{E}-12$ & 0.222 & 0.259 & 0.185 & $5.55 \mathrm{E}-14$ \\
\hline PF-R5IWb & $2.57 \mathrm{E}-12$ & 0.232 & 0.120 & 66.88 & $3.44 \mathrm{E}-12$ & 55 & $3.61 \mathrm{E}-12$ & 0.210 & 0.232 & 0.196 & $7.43 \mathrm{E}-14$ \\
\hline PF-R2IW & $2.98 \mathrm{E}-12$ & 0.266 & 0.141 & 72.15 & $3.20 \mathrm{E}-12$ & 60 & $3.99 \mathrm{E}-12$ & 0.230 & 0.181 & 0.164 & $5.41 \mathrm{E}-14$ \\
\hline WF-R250IW & $2.98 \mathrm{E}-12$ & 0.249 & 0.155 & 70.980 & $3.78 \mathrm{E}-12$ & 43 & $3.77 \mathrm{E}-12$ & 0.537 & 0.494 & 0.533 & $1.08 \mathrm{E}-12$ \\
\hline
\end{tabular}

The experimental data are presented in Figure 3 


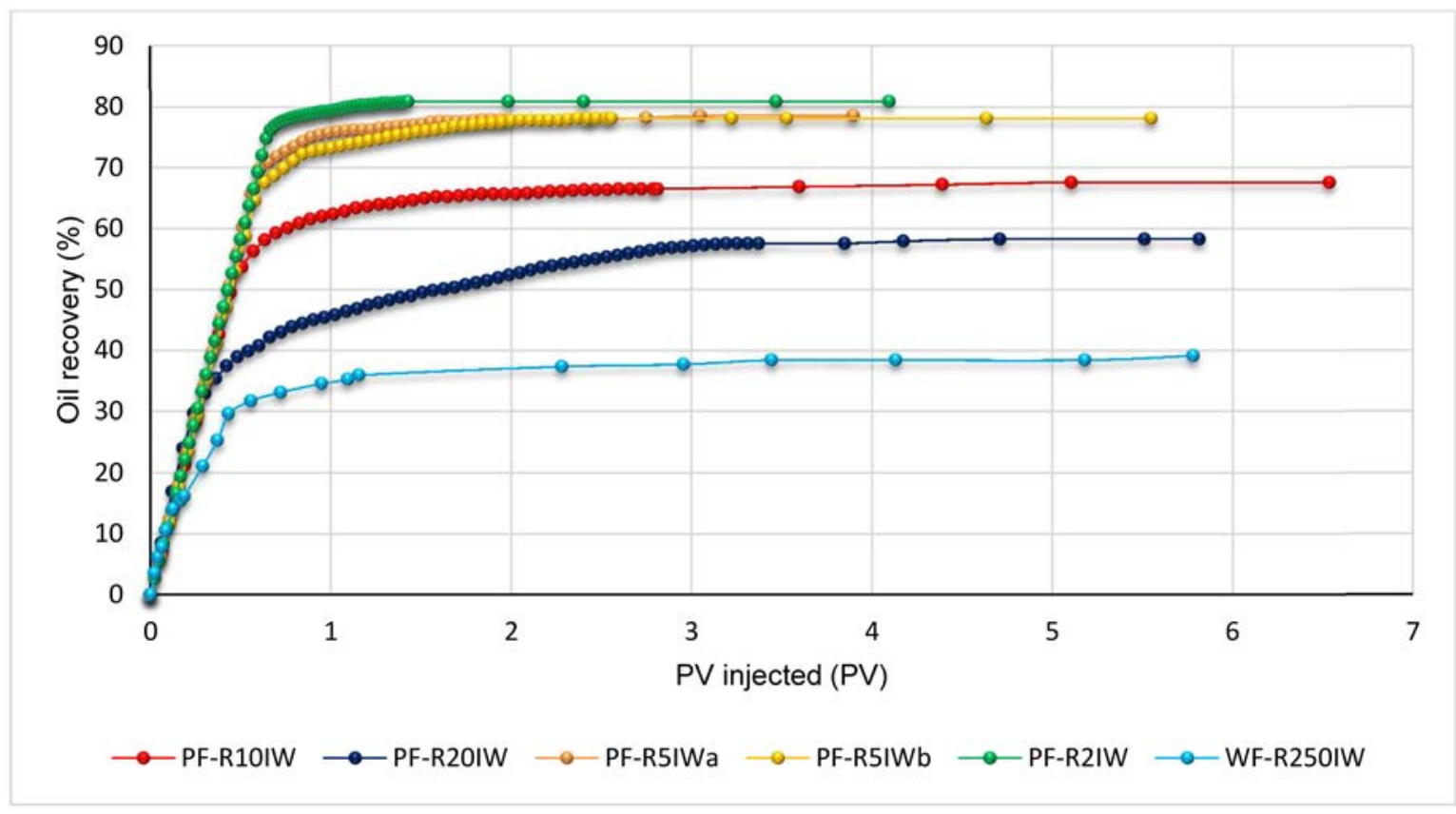

Figure 3-Oil recovery vs injected volume of the aqueous phase for different viscosity ratio.

We clearly see that the breakthrough increases when the viscosity ratio decreases and a higher oil recovery when viscosity ratio is low. It is also observed a smaller oil production tail after the breakthrough when the viscosity ratio is more favorable. This behavior can be attributed to a reduction of the flow instabilities when the viscosity ratio (oil / polymer solution) decreases improving sweep efficiency.

Mobility ratio, $\mathrm{M}$, which is a key parameter when dealing with flow instabilities is defined as:

$$
M=\frac{\lambda_{p}}{\lambda_{o}}=\frac{K_{r p}}{K_{r o}} \frac{\mu_{o}}{\mu_{p}}
$$

Where $\lambda_{p}$ and $\lambda_{o}$ are the polymer and oil mobilities and $k_{r p}$ and $k_{r o}$ refer to relative permeabilities of the polymer and oil phases. $k_{r p}$ is defined as $\left(k_{p} @ s o r\right) 2 / k w$ at constant flow where oil phase remains immobile. $k_{r o}$ is $\left(k_{o} @ S w i\right) 2 / k w$, measured after ageing.

The displacement becomes unstable if the mobility ratio $\mathrm{M}$ is greater than 1 . A high mobility ratio causes the instabilities (fingering) consequently the sweep efficiency decreases. Different final mobility ratio values are obtained for the different experiments at different viscosity ratios.

Table 3-Experimental data.

\begin{tabular}{|c|c|c|c|c|c|}
\hline $\begin{array}{c}\text { Viscosity ratio } \\
\text { (concentration) }\end{array}$ & $\begin{array}{c}2 \\
(3000 \mathrm{ppm})\end{array}$ & $\begin{array}{c}5 \\
(2400 \mathrm{ppm})\end{array}$ & $\begin{array}{c}10 \\
(1700 \mathrm{ppm})\end{array}$ & $\begin{array}{c}20 \\
(1500 \mathrm{ppm})\end{array}$ & Waterflooding \\
\hline Sor & 0.16 & 0.20 & 0.26 & 0.36 & 0.53 \\
\hline Sw & 0.84 & 0.80 & 0.74 & 0.64 & 0.47 \\
\hline $\mathrm{Pa}$ & 4943.51 & 4596.64 & 1954.78 & 3938.94 & 6323.33 \\
\hline $\mathrm{Kp}$ & $1.00 \mathrm{E}-12$ & $1.13 \mathrm{E}-12$ & $2.17 \mathrm{E}-12$ & $9.91 \mathrm{E}-13$ & $5.95 \mathrm{E}-13$ \\
\hline $\mathrm{Ko}$ & $4.00 \mathrm{E}-12$ & $3.61 \mathrm{E}-12$ & $3.38 \mathrm{E}-12$ & $3.50 \mathrm{E}-12$ & $3.78 \mathrm{E}-12$ \\
\hline Kw & $2.99 \mathrm{E}-12$ & $2.57 \mathrm{E}-12$ & $2.91 \mathrm{E}-12$ & $2.65 \mathrm{E}-12$ & $2.99 \mathrm{E}-12$ \\
\hline Krp Kro & 0.25 & 0.31 & 0.64 & 0.28 & 0.16 \\
\hline M & 0.59 & 1.61 & 7.55 & 5.41 & 42.92 \\
\hline
\end{tabular}

Viscous fingering appears when mobility ratio is unfavorable $(M>1)$ causing a poor sweep efficiency and high values of Sor. In Table 3 we summarize the data obtained with polymer flooding and waterflooding 
performed at different values of mobility ratio. A mobility ratio close to $M=1$ is observed in Table 2 when the viscosity ratio $R \mu \leq 5$ which indicates a better sweep efficiency than for the other cases.

Following the study of Juarez Morejon et al., (2018) the sweep efficiency can be related to the dispersion coefficient of the aqueous phase that is experimentally determined at the end of the water displacement when the oil is immobile. The dispersion coefficient is a macroscopic characteristic of the phases repartition inside the porous space. The measured data are reported in Figure 4 where we see a decrease of D when saturation increases. This confirms that a better sweep efficiency was achieved when viscosity ratio was decreased and viscous fingering was minimized. Oil mobilization throughout the porous medium is easier when viscosity ratio is smaller by reducing the dispersion of the aqueous phase and insuring a sharper displacement front.

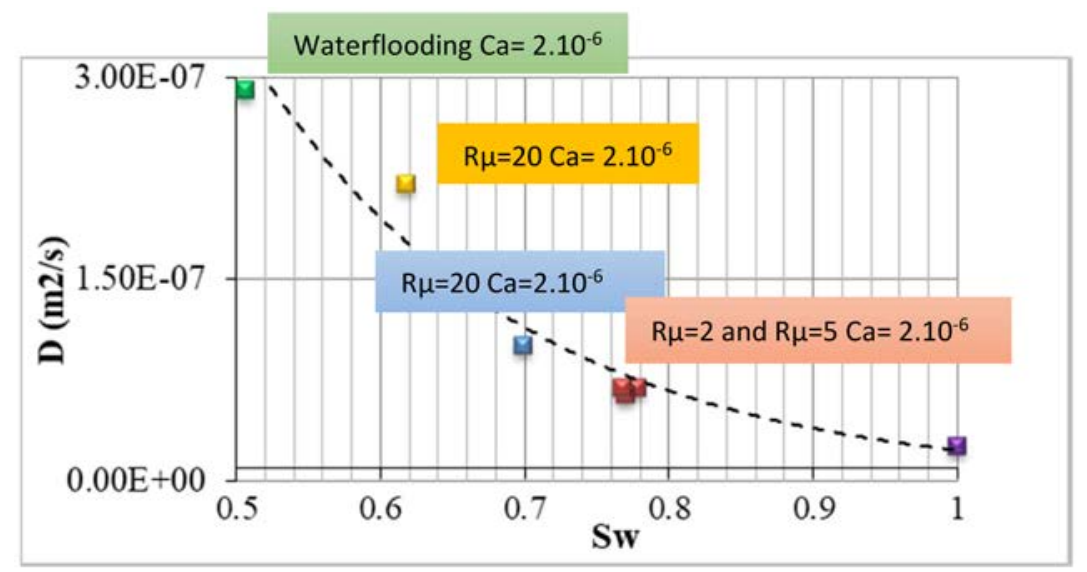

Figure 4-Dispersion coefficient versus water saturation measured at the end of the polymer and water flooding.

In Figure 5 we see that maximum oil recovery is obtained for a viscosity ratio close to 5 and that a reduction of the viscosity ratio, lower than 5, does not lead to an oil recovery improvement.

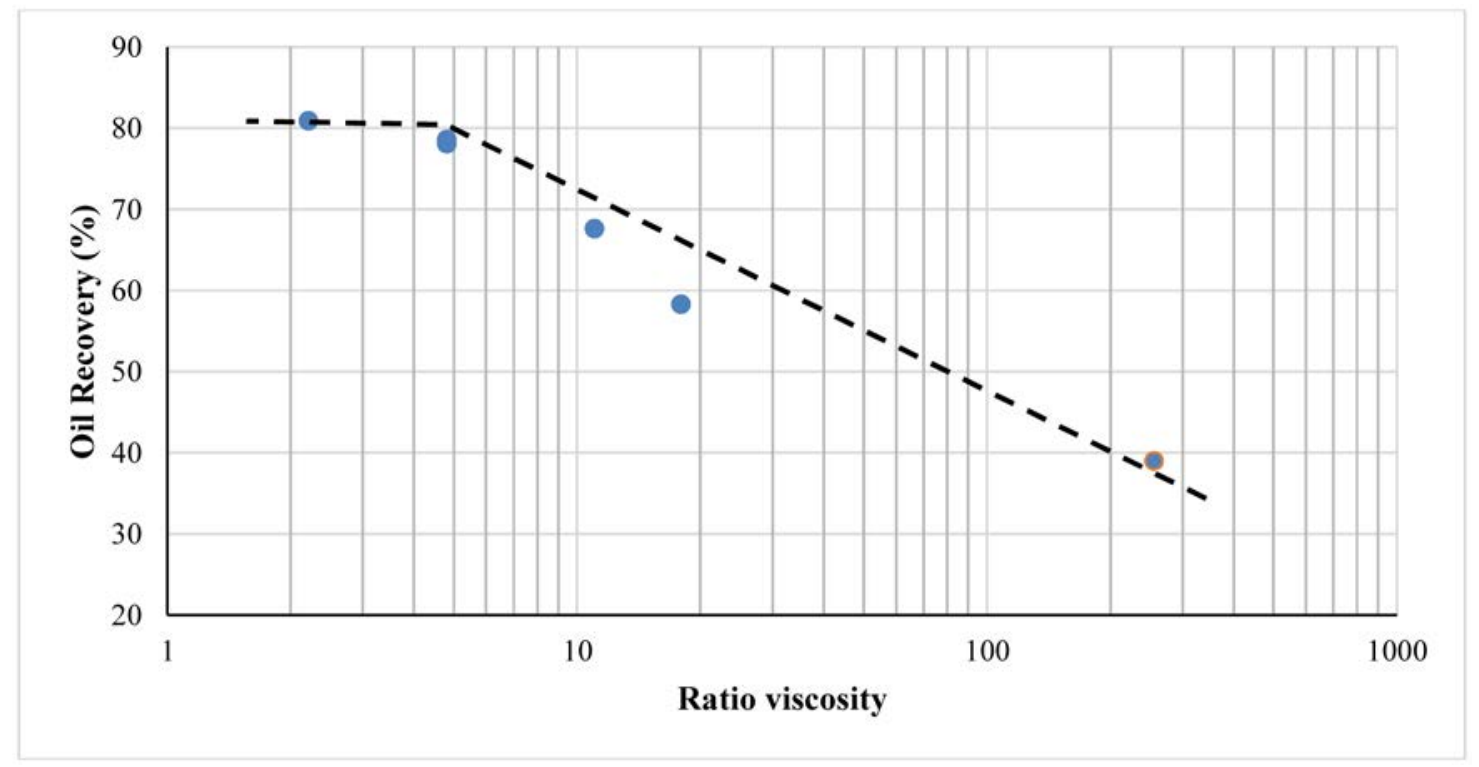

Figure 5-Final oil recovery versus viscosity ratio

The volume of polymer solution is not the only one concern that should be considered to optimize oil recovery but the mass of polymer. In Table 4 we report the mass of polymer that has been consumed to reach $95 \%$ of the final oil recovery and its corresponding value for each point of oil recovered. 
Table 4-Mass of polymer injected.

\begin{tabular}{|c|c|c|c|c|c|c|}
\hline $\begin{array}{c}\text { Concentration } \\
(\mathrm{ppm})\end{array}$ & $\begin{array}{c}\text { Capillary } \\
\text { number }\end{array}$ & $\begin{array}{c}\text { Viscosity } \\
\text { ratio }\end{array}$ & $\begin{array}{c}\text { PV } \\
\text { injected }\end{array}$ & $\begin{array}{c}\text { Oil recovery } \\
(95 \%)\end{array}$ & $\begin{array}{c}\text { Mass of polymer } \\
\text { injected (g) }\end{array}$ & $\begin{array}{c}\text { Mass of polymer } \\
\text { injected for each } \\
\text { point recovery }(\mathrm{g})\end{array}$ \\
\hline 1,500 & $1.902 \mathrm{E}-06$ & 20 & 2.5 & 55 & 0.364 & 0.0062 \\
\hline 1,700 & $2.102 \mathrm{E}-06$ & 10 & 1.5 & 65 & 0.318 & 0.0046 \\
\hline 2,400 & $2.346 \mathrm{E}-06$ & 5 & 0.89 & 74 & 0.202 & 0.0025 \\
\hline 3,000 & $2.372 \mathrm{E}-06$ & 2 & 0.66 & 76 & 0.24 & 0.003 \\
\hline
\end{tabular}

The analysis made on the mass of polymer required for $95 \%$ of the final recovery under the same experimental conditions $(\mathrm{Ca}=2 \times 10-6$ and $30 \%$ pre-degradation) show an optimal polymer mass (Figure 6).

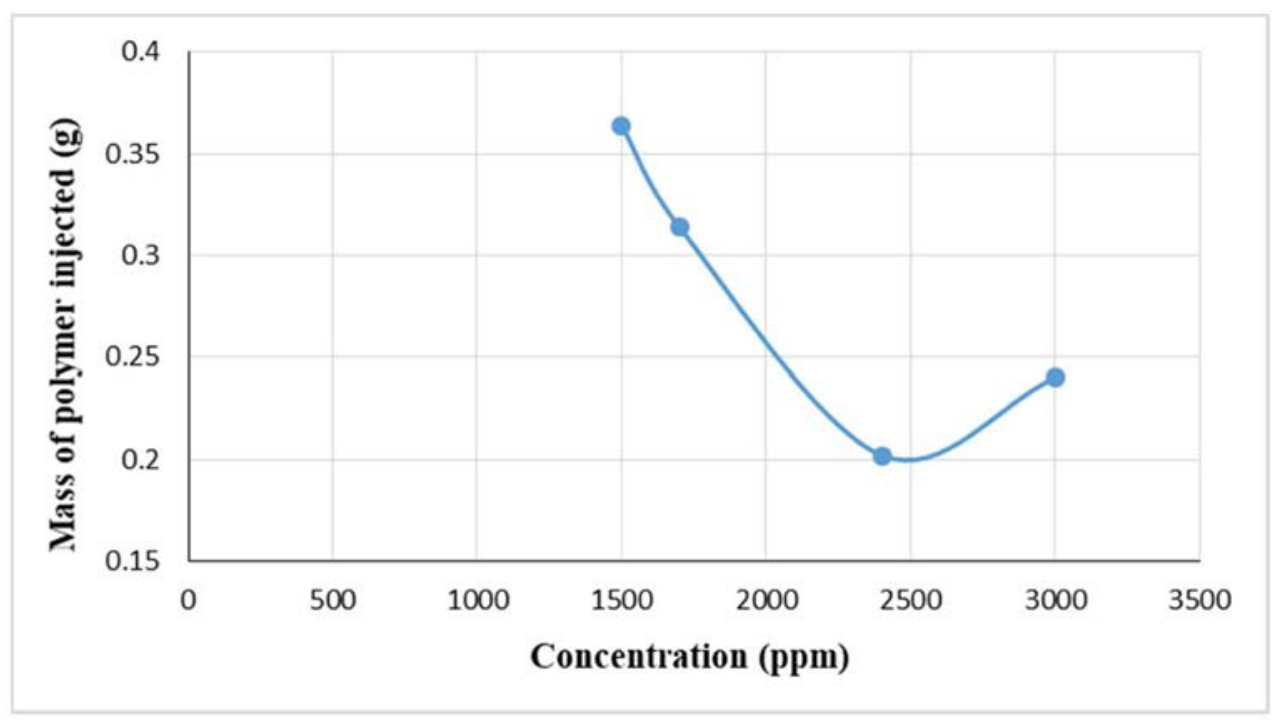

Figure 6-Mass of polymer needed to recover $95 \%$ of the final oil recovery.

Polymer slug injection. All polymer slug injections were carried out at same capillary number $(\mathrm{Ca}=2 \times 10-6)$ followed by chase water at same flow rate to minimize miscible viscous fingering at the rear of the polymer slug. The experimental results are reported in Table 5 where each experiment is described by a label where PF means (Polymer Flood) followed by the viscosity ratio (R10 for example, the viscosity ratio is equal to 10), and polymer slug size expressed in PV is in brackets. IW means Intermediate Wet, the use of minor letters is to mention duplicate experiments

The objective of these experiments is to reduce the mass of polymer injected to obtain maximum recovery. Three ratios were chosen $(R \mu=10, R \mu=5$ and $R \mu=2)$ with different polymer slugs. 
Table 5-Experimental data.

\begin{tabular}{|c|c|c|c|c|c|c|c|c|c|c|c|}
\hline Experiment & Kw $\left(\mathrm{m}^{2}\right)$ & $\phi$ & Swi & $\begin{array}{c}\text { OOIP } \\
(\mathrm{ml})\end{array}$ & $\begin{array}{c}(\text { Ko@Swi })_{1} \\
\text { before } \\
\text { ageing }\left(\mathrm{m}^{2}\right)\end{array}$ & $\begin{array}{c}\text { Ageing } \\
(\text { days })\end{array}$ & $\begin{array}{c}(\text { Ko@Swi })_{2} \\
\text { after ageing } \\
\left(\mathrm{m}^{2}\right)\end{array}$ & $\begin{array}{c}\text { Sor } \\
\text { gamma } \\
\text { ray }\end{array}$ & $\begin{array}{c}\text { Sor } \\
\text { Dispersion } \\
\text { test }\end{array}$ & $\begin{array}{c}\text { Sor } \\
\text { mass } \\
\text { balance }\end{array}$ & $\begin{array}{c}\left(\mathrm{Kw} @ \mathrm{Sor}_{2}\right. \\
(\mathrm{m} 2)\end{array}$ \\
\hline PF-R10(0.5)IW & $3.29 \mathrm{E}-12$ & 0.238 & 0.088 & 69.30 & $3.33 \mathrm{E}-12$ & 55 & $2.59 \mathrm{E}-12$ & 0.347 & 0.322 & 0.359 & $5.27 \mathrm{E}-14$ \\
\hline PF-R10(0.75)IW & $2.41 \mathrm{E}-12$ & 0.240 & 0.130 & 66.99 & $3.65 \mathrm{E}-12$ & 41 & $2.58 \mathrm{E}-12$ & 0.243 & 0.320 & 0.280 & $6.70 \mathrm{E}-14$ \\
\hline PF-R10(1)IW & $2.57 \mathrm{E}-12$ & 0.227 & 0.105 & 66.23 & $3.10 \mathrm{E}-12$ & 25 & $3.01 \mathrm{E}-12$ & 0.290 & 0.252 & 0.276 & $5.48 \mathrm{E}-14$ \\
\hline PF-R5(0.5)IWa & $3.35 \mathrm{E}-12$ & 0.240 & 0.113 & 66.52 & $3.48 \mathrm{E}-12$ & 55 & $3.85 \mathrm{E}-12$ & 0.328 & 0.304 & 0.262 & $7.66 \mathrm{E}-14$ \\
\hline PF-R5(0.5)IWb & $2.65 \mathrm{E}-12$ & 0.234 & 0.113 & 66.96 & $3.21 \mathrm{E}-12$ & 18 & $3.75 \mathrm{E}-12$ & 0.290 & 0.213 & 0.244 & $8.59 \mathrm{E}-14$ \\
\hline PF-R5(0.5)IWc & $3.50 \mathrm{E}-12$ & 0.229 & 0.107 & 65.63 & $3.27 \mathrm{E}-12$ & 20 & $3.54 \mathrm{E}-12$ & 0.281 & 0.226 & 0.246 & $6.74 \mathrm{E}-14$ \\
\hline PF-R5(0.75)IW & $1.98 \mathrm{E}-12$ & 0.238 & 0.131 & 66.04 & $3.14 \mathrm{E}-12$ & 68 & $2.51 \mathrm{E}-12$ & 0.289 & 0.229 & 0.2 & $5.48 \mathrm{E}-14$ \\
\hline PF-R2(0.5)IW & $2.16 \mathrm{E}-12$ & 0.240 & 0.137 & 66.45 & $2.73 \mathrm{E}-12$ & 88 & $2.52 \mathrm{E}-12$ & 0.198 & 0.193 & 0.213 & $5.63 \mathrm{E}-14$ \\
\hline
\end{tabular}

Viscosity ratio $\boldsymbol{R} \boldsymbol{\mu}=10$. In Figure 7 we compare the oil recovery obtained after injection of $0.5 \mathrm{PV}, 0.75 \mathrm{PV}$ and 1PV slug of polymer solution followed by chase water with the secondary polymer injection (6.5PV of polymer injection). We see that the final oil recovery does not change when polymer slug size is greater than $0.5 \mathrm{PV}$. However final oil recovery obtained after injection of a polymer slug of $0.5 \mathrm{PV}$ followed by chase water is lower ( $8 \%$ ) than the maximum value obtained during a secondary polymer flooding showing a lower sweep efficiency.

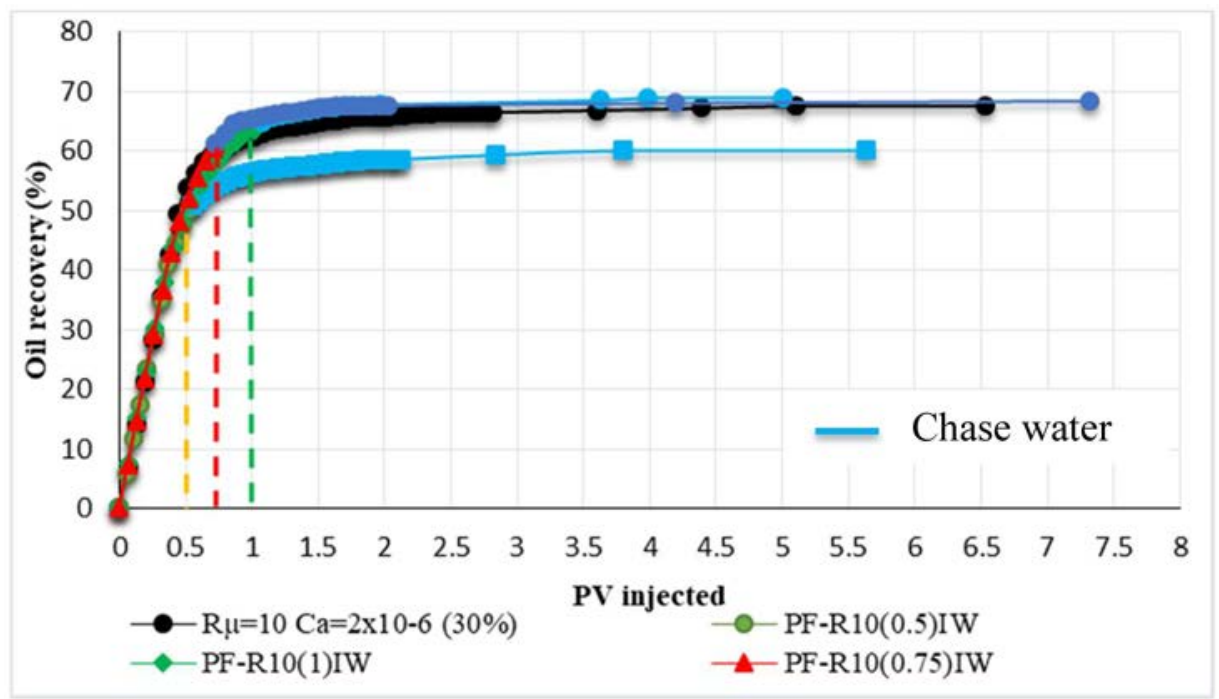

Figure $7-$ The influence of the effect of the size of the polymer plug $(0.5 \mathrm{PV}, 0.75 \mathrm{PV}$ and $1 \mathrm{PV})$ on the final recovery rate for the viscosity ratio $R \mu=10$ at same capillary number and same viscosity ratio (oil / polymer solution).

Figure 7 shows very clearly two groups of injections between $0.5 \mathrm{PV}$ and 0.75 or $1 \mathrm{PV}$. At the end of the polymer injection slug (1PV), the recovery of $63 \%$ is a value very similar to the final oil recovery $\approx 68 \%$ which means that the injection of water has little influence $(5 \%)$ on final recovery. There is then a gradual reduction in the influence of water injection when the size of the polymer slug increases.

Viscosity ratio $R \boldsymbol{\mu}=5$. Similar behavior than the one observed for $\mathrm{R} \mu=10$ is observed for $\mathrm{R} \mu=5$ with a triplicate coreflood that confirms the trend. The results are plotted in the Figure 8 where we see a final oil recovery close to $72 \%$ which is a final recovery lower than the recovery obtained with the polymer injection performed in secondary conditions. This result shows that the plug size of $0.5 \mathrm{Vp}$ is not sufficient to reach the same recovery value as in secondary condition $(\mathrm{RF} \approx 78 \%)$. 
However, for a slug size of $0.5 \mathrm{PV}$ the final oil recovery was higher for $\mathrm{R} \mu=5$ than $\mathrm{R} \mu=10$ due to viscosity ratio more favorable. The coreflood was repeated at a constant flow rate of $0.04 \mathrm{ml} / \mathrm{min}(\mathrm{Ca}=$ $2 \times 10-6$ ) for a polymer slug of 0.75 PV (Figure 8).

The Figure 8 shows the $0.75 \mathrm{PV}$ splug size is sufficient to achieve the same final recovery value as in secondary conditions $(\mathrm{RF}=78 \%)$.

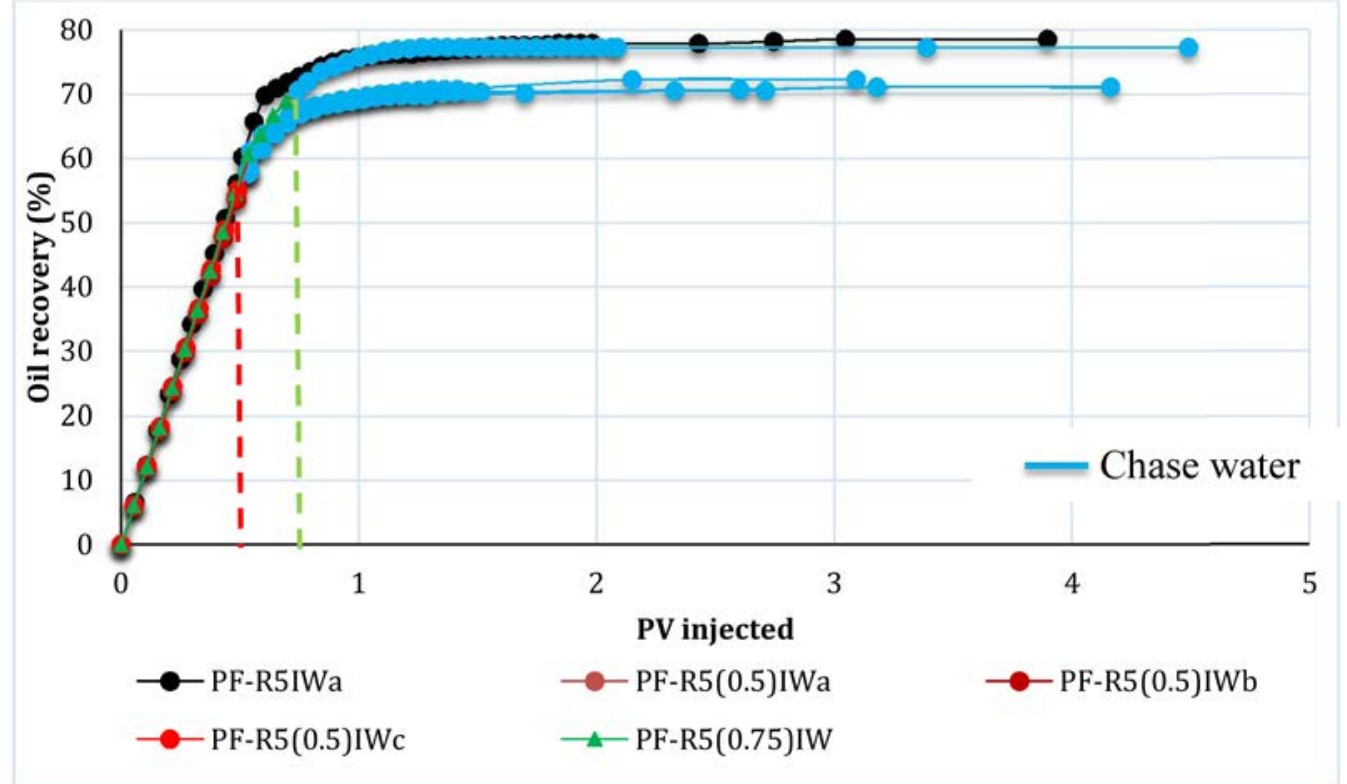

Figure 8-The influence of the effect of the size of the polymer plug (0.5PV and 0.75PV) on the final recovery rate for the viscosity ratio $R \mu=5$ at same capillary number and same viscosity ratio (oil / polymer solution).

Viscosity ratio $R \boldsymbol{\mu}=2$. The polymer injection was carried out at a constant flow rate of $\mathrm{Q}=0.02 \mathrm{ml} / \mathrm{min}$ $(\mathrm{Ca}=2 \times 10-6)$ a size of the polymer slug of $0.5 \mathrm{PV}$. The results in terms of recovery are plotted in Figure 9.

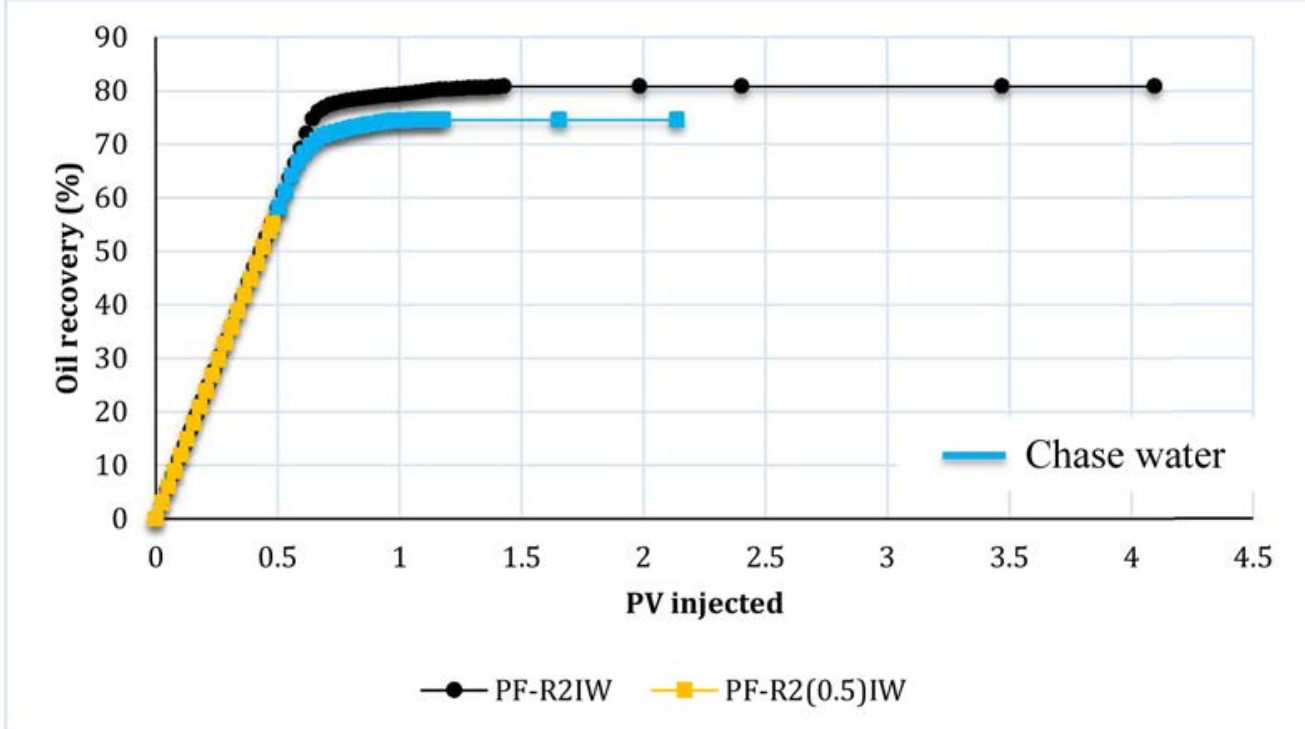

Figure 9-Oil recovery versus injected fluid (different slug sizes followed by chase water and secondary polymer flooding).

We observed a difference of 5\% between the secondary polymer flow and the injection of a polymer slug of 0.5PV. After the breakthrough, oil production continues with the injection of water at the same rate. 
There is an increment of oil production $\approx 20 \%$ with the injection, a much larger percentage than for the cases $\mathrm{R} \mu=5$ and $\mathrm{R} \mu=10$ for the same size of polymer slug $(0.5 \mathrm{PV})$.

The results (Figure 10) of the experiments dealing with the effect of the polymer slug size for the different viscosity ratios show an influence on the final oil recovery. The results of oil recovery for a polymer slug of $0.5 \mathrm{PV}$ at $\mathrm{R} \mu=2, \mathrm{R} \mu=5$ and $\mathrm{R} \mu=10$ show a final oil recovery close to final oil recovery obtained for secondary experiments, This difference is reduced when the mobility ratio is more favorable.

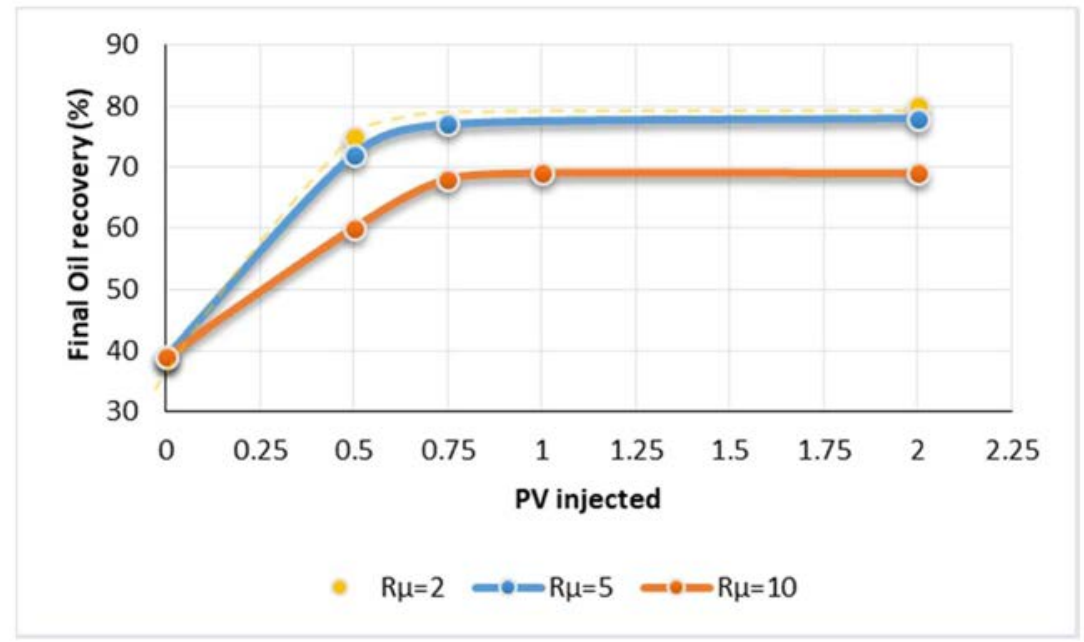

Figure 10-Final oil recovery values versus polymer slug for three different viscosity ratio. The values of $2 \mathrm{PV}$ correspond to secondary injection.

This type of injection strategy has two associated problems, a phenomenon of adsorption during the polymer injection and a dilution effect of polymer slug during water injection which decreases the sweep efficiency. This may explain these different behaviors of the corefloods between the slug size of $0.5 \mathrm{PV}$ and 0.75PV. An injection of $0.75 \mathrm{PV}$ is sufficient to avoid these dilution and adsorption effects which reduce the sweep efficiency.

\section{Discussion}

The effects of polymer slug size and viscosity ratio on final recovery, compared to the secondary polymer injection are summarized in Table 6.

Table 6-Summary results of polymer slug size.

\begin{tabular}{|c|c|c|c|c|c|c|}
\hline $\begin{array}{c}\text { Concentration } \\
(\mathrm{ppm})\end{array}$ & $\begin{array}{c}\text { Viscosity } \\
\text { ratio }\end{array}$ & $\begin{array}{c}\text { Final } \\
\text { recovery } \\
\%\end{array}$ & $\begin{array}{c}\text { Slug } \\
\text { polymer } \\
\text { size (PV) }\end{array}$ & $\begin{array}{c}\text { Final recovery } \\
\text { after polymer } \\
\text { slug } \%\end{array}$ & $\begin{array}{c}\text { Mass of inj. } \\
\text { Pol. }(\mathrm{g})\end{array}$ & $\begin{array}{c}\text { Mass of inj. } \\
\text { Pol. }(\mathrm{g}) \\
\text { /\%Recov. }\end{array}$ \\
\hline 1,700 & 10 & 68 & 0.5 & 60 & 0.064 & 0.001 \\
\hline 1,700 & 10 & 68 & 0.75 & 68 & 0.096 & 0.0014 \\
\hline 1,700 & 10 & 68 & 1 & 68 & 0.124 & 0.0018 \\
\hline 2,400 & 5 & 78 & 0.5 & 72 & 0.092 & 0.0012 \\
\hline 2,400 & 5 & 78 & 0.75 & 78 & 0.14 & 0.0018 \\
\hline 3,000 & 2 & 80 & 0.5 & 75 & 0.115 & 0.0015 \\
\hline
\end{tabular}


Whatever the viscosity ratio we clearly see that the optimal oil recovery is reached when the polymer slug size is greater than $0.5 \mathrm{PV}$. There is not much difference in term of oil sweeping when the polymer slug size is $0.75 \mathrm{PV}$ or $1 \mathrm{PV}$ nor secondary polymer flooding. Considering that the two main concerns when dealing with polymer flooding are viscous fingering and polymer adsorption we can discuss our experimental data in the following way.

Viscous fingering can explain the differences of final oil recoveries that are obtained for different viscosity ratio, this point has been shown in the first part of the paper. However it is necessary to consider viscous fingering that may occur upstream of the polymer slug when injecting chase water which viscosity is always less that the one of the polymer slug. Viscous fingers are able to develop and breakthrough the polymer slug if its size is not long enough to allow a good sweeping. This conjecture may explain why final recovery obtained after $0.5 \mathrm{PV}$ slug size injected is always lower than the ones obtained when the polymer slug size is bigger.

Even if polymer adsorption is low in our conditions (Juarez Morejon, 2018), part of the injected polymer will not participate to the incremental oil recovery due to viscosity increase. This is particularly true as polymer slug size is small. This effect will reduce the effective size of the slug and promote viscous fingering development.

\section{Conclusions}

We present experimental coreflood performed with a sandstone at intermediate wettability showing the influence of viscosity ratio and polymer slug size on the final recovery. The main conclusions are summarized here below.

- For a secondary polymer injection maximum oil recovery is obtained for $\mathrm{M}=1 ;(\mathrm{R} \mu=5$.), no more oil was produced when reducing the viscosity ratio

- When injecting a polymer slug $(\mathrm{R} \mu=5)$ followed by chase water, we observed an optimal value of the polymer slug of $\approx 0.75 \mathrm{PV}$ leading to a maximum oil recovery.

- Viscous fingering and polymer adsorption are the causes of the low sweep efficiency that is observed for a small polymer slug size.

- The polymer concentration can be optimized to reduce the ratio used polymer/recovered oil.

Acknowledgement

The authors thank Total for supporting this study and for the authorization to publish this paper

\section{Nomenclature}

$$
\begin{aligned}
& =\text { Water fractional flow function, - } \\
\mathrm{C} & =\text { concentration }(\mathrm{ppm}) \\
\mathrm{Ca} & =\text { capillary number } \\
\mathrm{D} & =\text { dispersivity }\left(\mathrm{m}^{2} / \mathrm{s}\right) \\
\mathrm{kw} & =\text { permeability }\left(\mathrm{m}^{2}\right) \\
\mathrm{ko@swi} & =\text { oil permeability at Swi }\left(\mathrm{m}^{2}\right) \\
\mathrm{kw} @ \mathrm{sor} & =\text { water permeability at Sor }\left(\mathrm{m}^{2}\right) \\
\mathrm{kp} @ \mathrm{sor} & =\text { polymer permeability at } \operatorname{Sor}\left(\mathrm{m}^{2}\right) \\
\mathrm{K}_{\mathrm{rp}} & =\text { relative permeability of polymer } \\
\mathrm{K}_{\mathrm{ro}} & =\text { relative permeability of oil } \\
\mathrm{M} & =\text { Mobility ratio } \\
\mathrm{OOIP} & =\text { original oil in place } \\
\mathrm{PV} & =\text { Pore Volume } \\
\mathrm{Q} & =\text { flow rate }\left(\mathrm{m}^{3} / \mathrm{s}\right)
\end{aligned}
$$




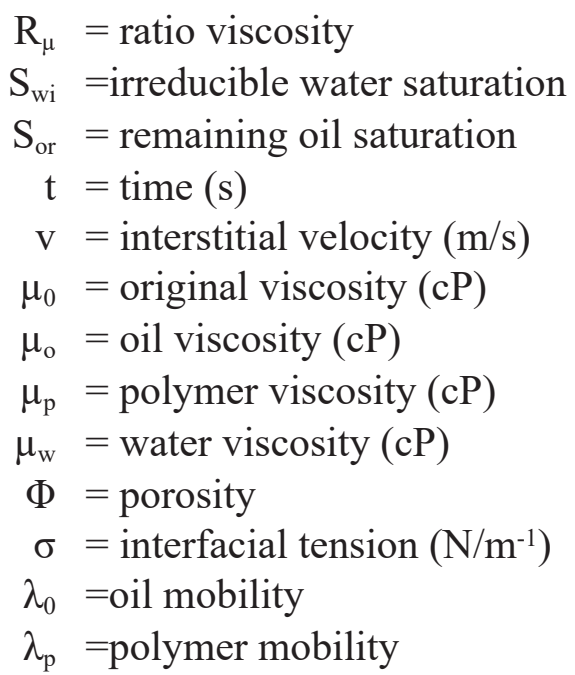

\section{References}

Claridge,E. L. (1978). Method for Designing Graded Viscosity Banks. Soc Pet Eng AIME J, 18 (5), 315-324. http:// dx.doi.org/10.2118/6848-pa

Chuoke, R. L., van Meurs, P., \& van der Poel, C. (1959). The instability of slow, immiscible, viscous liquid-liquid displacements in permeable media. Petroleum Transactions, AIME, 216, 188-194. http://dx.doi.org/SPE-1141-G

Doorwar, Shashvat, Mohanty, Kishore K., Fingering Function for Unstable Immiscible Flows, SPE 173290-MS, 2015.

Hagoort, J. (1974). Displacement Stability of Water Drives in Water-Wet Connate-Water-Bearing Reservoirs. Soc Pet Eng AIME J, 14 (1), 63-74. http://dx.doi.org/10.2118/4268-pa

Juarez-Morejon, J. L., Bertin, H., Oman, A. et al. 2017. Spontaneous Imbibition as Indicator of Wettability Change During Polymer Flooding. IOR 2017-19th European Symposium on Improved Oil Recovery, Stavanger, Norway, DOI: 10.3997/2214-4609.201700334

Juarez Morejon, J. L., Bertin, H., Oman A., Hamon G., Cottin, C., Morel D., Romero, C., Bourdarot, G. (2018). SPE 174672, SPE EUROPEC, Copenhagen, Denmark, 11-14 June 2018.

Koval, E. J. (1963). A Method for Predicting the Performance of Unstable Miscible Displacement in Heterogeneous Media. Society of Petroleum Engineers Journal, 3 (02), 145-154. http://dx.doi.org/10.2118/450-pa

Mungan, N, Improved waterflooding through mobility control, The Canadian Journal of Chemical Engineering, Vol. 49, February, 1971.

Peksa, A. E., Wolf, K. H. A. A., \& Zitha, P. L. J. (2015). Bentheimer sandstone revisited for experimental purposes. MarineandPetroleumGeology,67,701-719.http://dx.doi.org/10.1016/j.marpetgeo.2015.06.001

Peters, E. J., \& Flock, D. L. (1981). Onset of Instability During Two-Phase Immiscible Displacement in Porous Media. Society of Petroleum Engineers Journal, 21 (2), 249-258. http://dx.doi.org/10.2118/8371-PA

Pozzi, A. L., \& Blackwell, R. J. (1963). Design of Laboratory Models for Study of Miscible Displacement. Society of Petroleum Engineers Journal, 3 (01), 28-40. http://dx.doi.org/10.2118/445-pa

Rapoport, L. A., \& Leas, W. J. (1953). Properties of Linear Waterfloods. Journal of Petroleum Technology, 5 (05), 139-148. http://dx.doi.org/10.2118/213-g

Saffman, P. G., Taylor, G. I. The pene-tration of a fluid into a porous medium or Hele-Shaw cell containing a more viscous liquid. Proc. R. Soc. London SeT. A 245 :312-29. 1958.

Skauge T., Vik B. F.,OrmehaugP. A., Jatten B. K.,, Kippe V., SkjevrakI., Standnes D.C., Uleberg K., Skauge A., Polymer Flood at Adverse Mobility Ratio in 2D Flow by X-ray Visualization, SPE EOR169740-MS Conference at Oil and Gas West Asia, 31 March-2 April, Muscat, Oman, 2014

Uzoigwe, A. C., Scanlon, F. C., \& Jewett, R. L. (1974). Improvements in Polymer Flooding: the Programmed Slug and the Polymer-Conserving Agent. JPT, Journal of Petroleum Technology, 26, 33-41. http://dx.doi.org/10.2118/4024-PA

Vishnudas, R., \& Chaudhuri, A. (2017). A comprehensive numerical study of immiscible and miscible viscous fingers during chemical enhanced oil recovery. Fuel, 194, 480-490. http://dx.doi.org/10.1016/jluel.2017.01.014 